\title{
Electrocautery causes more ischemic peritoneal tissue damage than ultrasonic dissection
}

\author{
Richard P. G. ten Broek • Joyce Wilbers • \\ Harry van Goor
}

Received: 14 May 2010/ Accepted: 11 November 2010/Published online: 8 December 2010

(C) The Author(s) 2010. This article is published with open access at Springerlink.com

\begin{abstract}
Background Minimizing peritoneal tissue injury during abdominal surgery has the benefit of reducing postoperative inflammatory response, pain, and adhesion formation. Ultrasonic dissection seems to reduce tissue damage. This study aimed to compare electrocautery and ultrasonic dissection in terms of peritoneal tissue ischemia measured by microdialysis.

Methods In this study, 18 Wistar rats underwent a median laparotomy and had a peritoneal microdialysis catheter implanted in the left lateral sidewall. The animals were randomly assigned to receive two standard peritoneal incisions parallel to the catheter by either ultrasonic dissection or electrocautery. After the operation, samples of microdialysis dialysate were taken every $2 \mathrm{~h}$ until $72 \mathrm{~h}$ postoperatively for measurements of pyruvate, lactate, glucose, and glycerol, and ratios were calculated.

Results The mean lactate-pyruvate ratio (LPR), lactateglucose ratio (LGR), and glycerol concentration were significantly higher in the electrocautery group than in the ultrasonic dissection group until respectively 34,48 , and $48 \mathrm{~h}$ after surgery. The mean areas under the curve (AUC) of LPR, LGR, and glycerol concentration also were higher in the electrocautery group than in the ultrasonic dissection group $(4,387$ vs. $1,639, P=0.011 ; 59$ vs. $21, P=0.008$; 7,438 vs. $4,169, P=0.008$, respectively).

Conclusion Electrosurgery causes more ischemic peritoneal tissue damage than ultrasonic dissection.
\end{abstract}

R. P. G. ten Broek and J. Wilbers contributed equally to this work.

R. P. G. ten Broek · J. Wilbers · H. van Goor $(\varangle)$

Department of Surgery, Radboud University Nijmegen Medical Centre, P.O. Box 9101, 6500 HB Nijmegen, The Netherlands

e-mail: H.vanGoor@CHIR.umcn.nl
Keywords Adhesions · Electrocautery · Ischemia · Microdialysis · Ultrasonic dissection

Peritoneal tissue ischemia resulting from dissection, electrocautery, sutures, carbon dioxide $\left(\mathrm{CO}_{2}\right)$ insufflation (in laparoscopy), and retraction by instruments seems unavoidable in abdominal surgery. Ischemia induces an inflammatory response of the peritoneum, which is associated with postoperative pain, abdominal distension, and adhesion formation [1].

A good surgical technique is advocated to minimize tissue damage and peritoneal ischemia. The type of dissection device used during surgery may have an impact on the degree of ischemic damage. Recent reports suggest that ultrasonic dissection is superior to electrocautery (e.g., causing less deep tissue injury and less profound ischemia). The data in these reports are derived predominantly from vascular and thoracic surgery studies showing less endothelial injury and vasospasm [2, 3]. Despite the wide usage of electrocautery and ultrasonic dissection in laparoscopic and open abdominal surgery, little is known about their impact on peritoneal ischemia or about related early and long-term postoperative outcomes [4].

Microdialysis is capable of continuously monitoring extracellular space chemistry, avoiding serial tissue sampling. In the past, it was predominantly used in neurointensive care monitoring of cerebral ischemia and in metabolic control. Currently, microdialysis is more widely applied to include early detection of visceral ischemia after abdominal surgery [5]. It proves to be a simple and reliable technique for continuous monitoring of tissue responses to injury.

The current study aimed to assess the extent of ischemic peritoneal damage as determined by microdialysis in 
animals undergoing surgery with either electrocautery or ultrasonic dissection.

\section{Materials and methods}

\section{Animals}

This study used 18 male Wistar rats weighing 250 to $300 \mathrm{~g}$ (Harlan BV, Horst, The Netherlands). The animals were acclimated to laboratory conditions with day-night cycles of $12 \mathrm{~h}$ for 1 week before commencement of experiments. The rats were housed under standard conditions in filtertopped cages, 2 rats per cage before surgery and 1 rat per cage after surgery, with free access to animal chow (Hope Farms, Woerden, The Netherlands) and water.

The study was approved by and conducted in accordance with the guidelines of the Animal Ethics Review Committee of the Faculty of Medicine, Radboud University Nijmegen, The Netherlands.

\section{Study design}

The 18 rats were randomly assigned to a group undergoing either peritoneal tissue incision with ultrasonic dissection (UD group, $n=9$ ) or electrocautery (EC group, $n=9$ ). Peritoneal microdialysis was performed for $72 \mathrm{~h}$ after surgery, and 2-h samples were obtained to determine metabolic and ischemic parameters. The rats were killed 3 days after surgery to check the position of the catheters.

\section{Surgical procedure}

The animals were fasted overnight and anesthetized using isofluorane, nitrous oxide, and oxygen. Procedures were performed under sterile conditions. After shaving and disinfection with $70 \%$ ethanol, the rats underwent a median laparotomy incision with a total length of $4 \mathrm{~cm}$ (Fig. 1A). A microdialysis catheter was implanted in the left lateral parietal peritoneum between the peritoneum and the abdominal muscle and fixed with nonresorbable 5/0 polypropylene. The connecting tubes were tunneled subcutaneously to the top of the animal's head.

Two parallel incisions in the parietal peritoneum with a length of $2 \mathrm{~cm}$ were made, both $5 \mathrm{~mm}$ from the catheter. (Fig. 1B) The incisions were made using an ultrasonic "coagulation" blade (Harmonic Scalpel; Johnson and Johnson, Amersfoort, the Netherlands) in the UD group and using an electrocautery blade (Valleylab, Boulder, CO, USA) in the EC group. The ultrasonic coagulation was fixed at level 3 (the coagulation level normally used in humans). In the EC group, the lesions were made with a fixed rate of energy (blend 1/30 W). The contact time with the tissue was
A

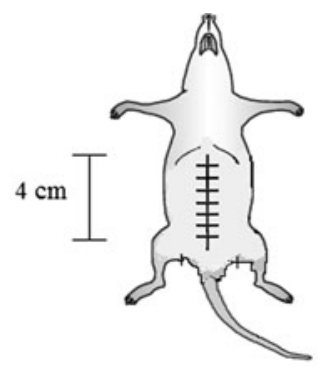

B

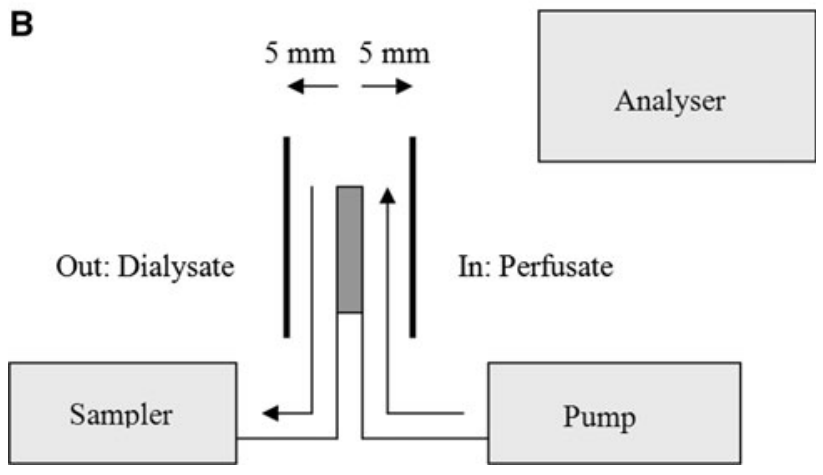

Fig. 1 Surgical procedure and microdialysis system. A Median laparotomy. B Two parallel incisions in the parietal peritoneum on both sides of the microdialysis catheter at a distance of $5 \mathrm{~mm}$ from the probe. The catheter is connected to a pump and automatic sampler

exactly $3 \mathrm{~s}$ for both methods of injury. The abdominal wall was closed with $3 / 0$ polyglactin and the skin with agraves.

At the end of surgery, all the animals received buprenorphine hydrochloride $0.1 \mathrm{mg} / \mathrm{kg}$ intramuscularly and $10 \mathrm{ml}$ of $0.9 \% \mathrm{NaCl}$ subcutaneously. The animals were killed 3 days after surgery by $\mathrm{O}_{2} / \mathrm{CO}_{2}$ asphyxiation. The abdomen was reopened, and the catheter was inspected for location and removed.

\section{Microdialysis}

The ClinicalMicrodialysisAnalyzer/20 (CMA microdialysis, Stockholm, Sweden) was used for microdialysis. The CMA/20 microdialysis probe had a concentric construction of a soft flexible inner and outer plastic tube covered at the tip by a membrane. The probe had an outer diameter of $0.5 \mathrm{~mm}$ and was fitted with 200-mm-long inlet and outlet tubings. The membrane had a length of $10 \mathrm{~mm}$ and a cutoff of 100,000 daltons. The maximal flow rate was $10 \mu \mathrm{l} / \mathrm{min}$.

After the microdialysis catheter had been inserted into the tissue, it was connected to a microdialysis pump (CMA 102; CMA, Stockholm, Sweden) and perfused at a flow rate of $0.3 \mu \mathrm{l} / \mathrm{min}$. The perfusate consisted of a buffer solution $\left(\mathrm{NaCl} 147 \mathrm{mmol} / \mathrm{l}, \mathrm{KCl} 2.8 \mathrm{mmol} / \mathrm{l}, \mathrm{CaCl}_{2} 3.4 \mathrm{mmol} / \mathrm{l}\right.$, $\mathrm{K}_{2} \mathrm{HPO}_{4} 0.6 \mathrm{mmol} / \mathrm{l}, \mathrm{MgCl}_{2} 1.2 \mathrm{mmol} / \mathrm{l}$, ascorbate adjusted to $\mathrm{pH}$ 6.9) and $40 \mathrm{mg} / \mathrm{ml}$ of Dextran 70 (Amersham Pharmacia Biotech AB, Uppsala, Sweden) administered with a $2.5-\mathrm{ml}$ glass syringe (CMA, Stockholm, Sweden). 
Sampling and biochemical analysis

The first sample was collected $2 \mathrm{~h}$ after laparotomy by a synchronized sampler (CMA/140, CMA microdialysis; CMA, Stockholm, Sweden), and automatic sampling was continued every $2 \mathrm{~h}$ for a total duration of 3 days. The samples were stored at $-20^{\circ} \mathrm{C}$.

The concentrations of peritoneal extracellular pyruvate, lactate, glucose, and glycerol were measured immediately after the whole experiment using ordinary enzymatic methods with a microdialysis-analyzer (CMA 600; CMA).

\section{Statistical analysis}

Lactate-pyruvate and lactate-glucose ratios were calculated. Data of continuous variables are expressed as means and $95 \%$ confidence intervals (CI). A two-sided $t$-test was calculated to evaluate any differences between two categorical variables. The area under the curve (AUC) was calculated by GraphPad, and data are expressed as mean and range. The Wilcoxon test was performed to evaluate any differences between continuous variables at different intervals. Statistical analysis was performed using SPSS 14.0 (SPSS, Chicago, IL) and GraphPad (GraphPad Prism 4.00; GraphPad Software, San Diego, CA). A $P$ value less than 0.05 was considered significant.

\section{Results}

All the animals survived the experimental period, and a $100 \%$ sampling was obtained. All the catheters remained in position during the study period.

The unrefined data of the separate animals showed the same tendency over time within one treatment group (Fig. 2). The means and 95\% confidence intervals of metabolite concentrations at the time points are shown in Fig. 3. Figure 3 shows the AUC, which represents the total concentration of variables in the 72 -h period.

\section{Glucose}

The immediate postoperative mean glucose concentration was significantly lower in the EC group $(4.7 \mathrm{mmol} / \mathrm{l})$ than in the UD group $(5.4 \mathrm{mmol} / \mathrm{l} ; P<0.01)$. In the animals treated with electrocautery, the mean glucose concentration decreased in the first $12 \mathrm{~h}$, reaching the lowest value of $3.0 \mathrm{mmol} / \mathrm{l}$, then increased again. The UD group showed an almost straight curve, with values of 4.9 to $5.7 \mathrm{mmol} / \mathrm{l}$.

The mean values in the EC group were significantly lower than in the UD group for the first $36 \mathrm{~h}$ after surgery. The total glucose concentration, represented by the AUC, was lower in the EC group $(316 \mathrm{mmol} / \mathrm{l} \mathrm{h})$ than in the UD group $(380 \mathrm{mmol} / \mathrm{l} \mathrm{h} ; P=0.008)$.

\section{Lactate}

In the immediate postoperative period, the mean lactate concentration was significantly higher after electrocautery $(3.4 \mathrm{mmol} / \mathrm{l})$ than after ultrasonic dissection $(2.0 \mathrm{mmol} / \mathrm{l}$; $P<0.01)$. Within the first $9 \mathrm{~h}$ postoperatively, a peak of $6 \mathrm{mmol} / \mathrm{l}$ was reached in the EC group, followed by a decline to baseline. In contrast, the UD group did not reach a peak and remained at levels 1.4 and $2.1 \mathrm{mmol} / \mathrm{l}$. The mean lactate values were significantly higher in the EC group than in the UD group until $48 \mathrm{~h}$ postoperatively. The total lactate concentration was significantly higher in the EC group (AUC, $233 \mathrm{mmol} / \mathrm{l} \mathrm{h}$ ) than in the UD group (AUC, $112 \mathrm{mmol} / \mathrm{l} \mathrm{h} ; P=0.008$ ).

\section{Glycerol}

From the beginning, the mean glycerol concentration (a direct parameter for tissue ischemia) was significantly higher in the EC group $(210 \mu \mathrm{mol} / \mathrm{l})$ than in the UD group $(104 \mu \mathrm{mol} / \mathrm{l}$; $P<0.01$ ). The EC group showed a gradual decline until $50 \mathrm{~h}$ after surgery. The animals treated with ultrasonic dissection showed a similar tendency, but the concentrations were lower and declined only from 104 to $47 \mu \mathrm{mol} / \mathrm{l}$. The total glycerol concentration in the EC group (mean AUC, 7,438 $\mu \mathrm{mol} / \mathrm{l} \mathrm{h}$ ) was almost two times higher than in the UD group (mean AUC, $4,169 \mu \mathrm{mol} / \mathrm{l} \mathrm{h} ; P=0.008$ ).

\section{Lactate-pyruvate ratio}

The mean calculated lactate-pyruvate ratio immediately after surgery was significantly higher in the EC group than in the UD group (105 vs. 30; $P<0.01$ ). The EC group reached ratios comparable with those of the UD group at $50 \mathrm{~h}$ after surgery. The animals treated with ultrasonic dissection showed an almost straight curve, with ratios between 14 and 30. The mean values were significantly higher in the EC group than in the UD group until $34 \mathrm{~h}$ after surgery. The mean AUC of the lactate-pyruvate ratio was higher in the EC group than in the UD group $(4,387$ vs. 1,$639 ; P=0.011)$.

Lactate-glucose ratio

The mean calculated lactate-glucose ratio was significantly higher in the EC group than in the UD group (0.74 vs. 0.37 ; $P<0.01)$. A peak was reached $22 \mathrm{~h}$ after surgery, with a ratio of 1.8. Thereafter, it declined to values between 0.2 and 0.4. The animals treated with ultrasonic dissection had ratios between 0.2 and 0.4 . The mean values were significantly higher in the EC group until $48 \mathrm{~h}$ after surgery. The 
Fig. 2 Unrefined data.

Microdialysis parameters in animals that had surgery with ultrasonic dissection (UD) $(n=9)$ or electrocautery (EC) $(n=9)$
GLUCOSE UD

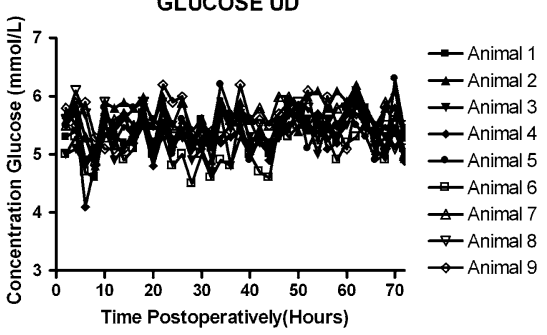

PYRUVATE UD

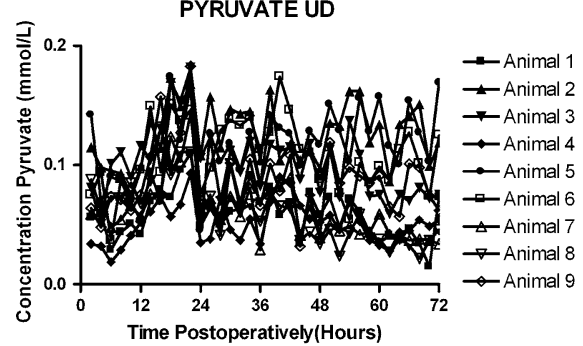

LACTATE UD

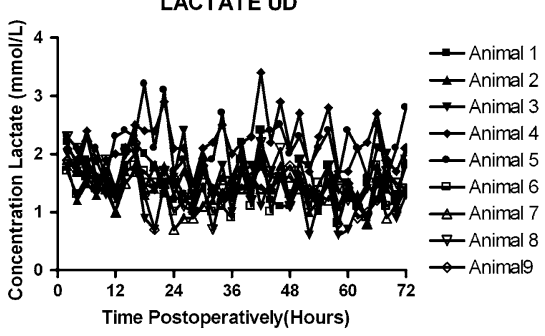

GLYCEROL UD

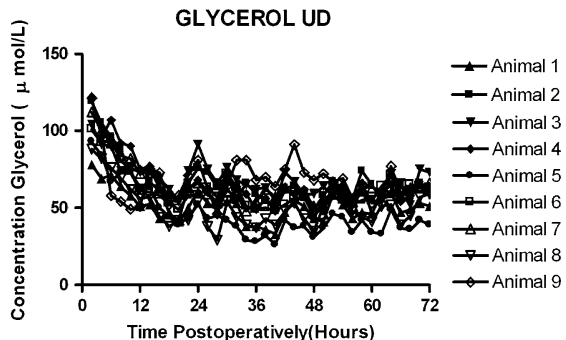

LACTATE/PYRUVATE UD

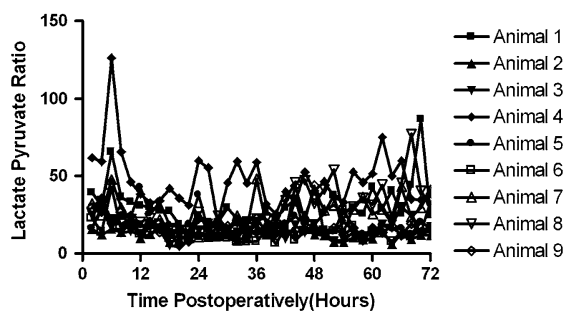

LACTATE/GLUCOSE UD

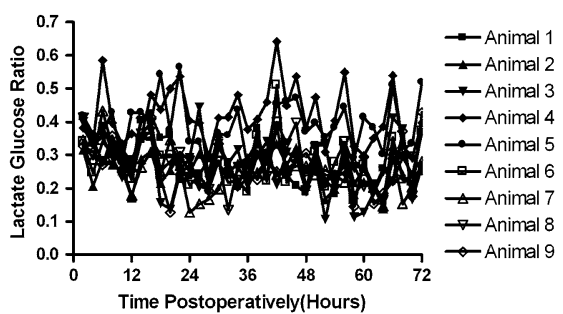

GLUCOSE EC

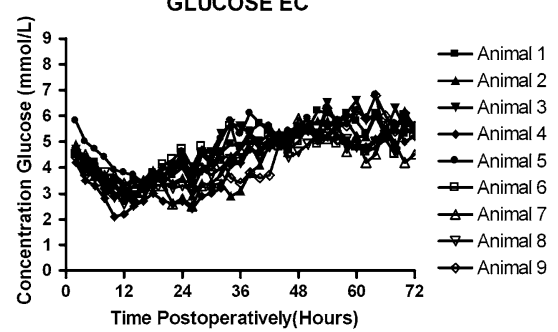

LACTATE EC

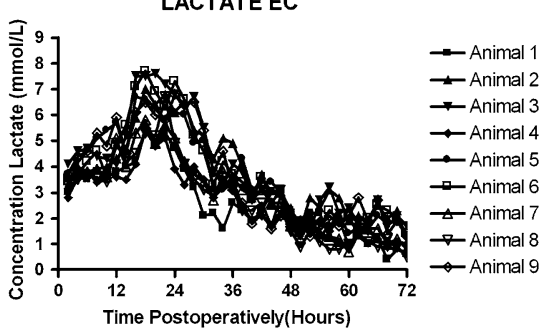

GLYCEROL EC

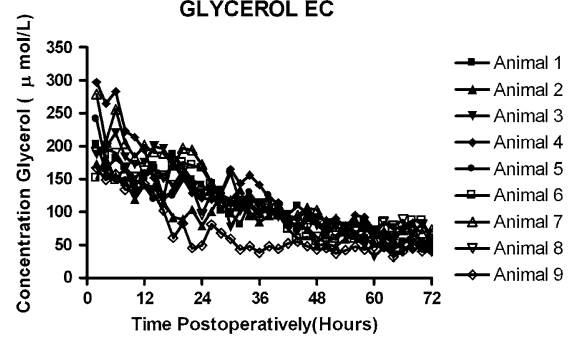

LACTATE/PYRUVATE EC

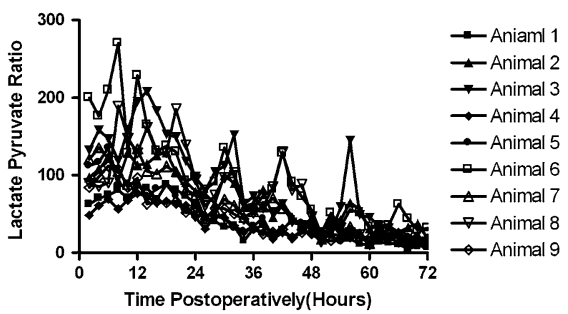

LACTATE/GLUCOSE EC

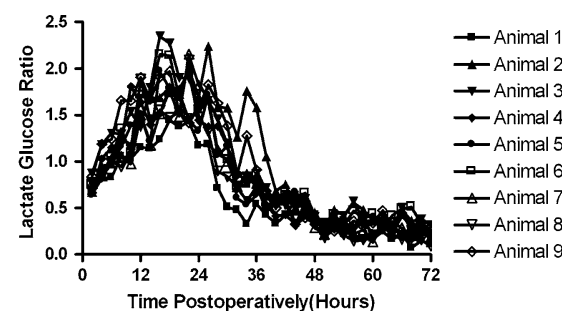


Fig. 3 Microdialysis parameters in animals that had surgery with ultrasonic dissection (UD) $(n=9)$ or electrocautery (EC) $(n=9)$.

Values are expressed as means and $95 \%$ confidence intervals.

$* P<0.01$
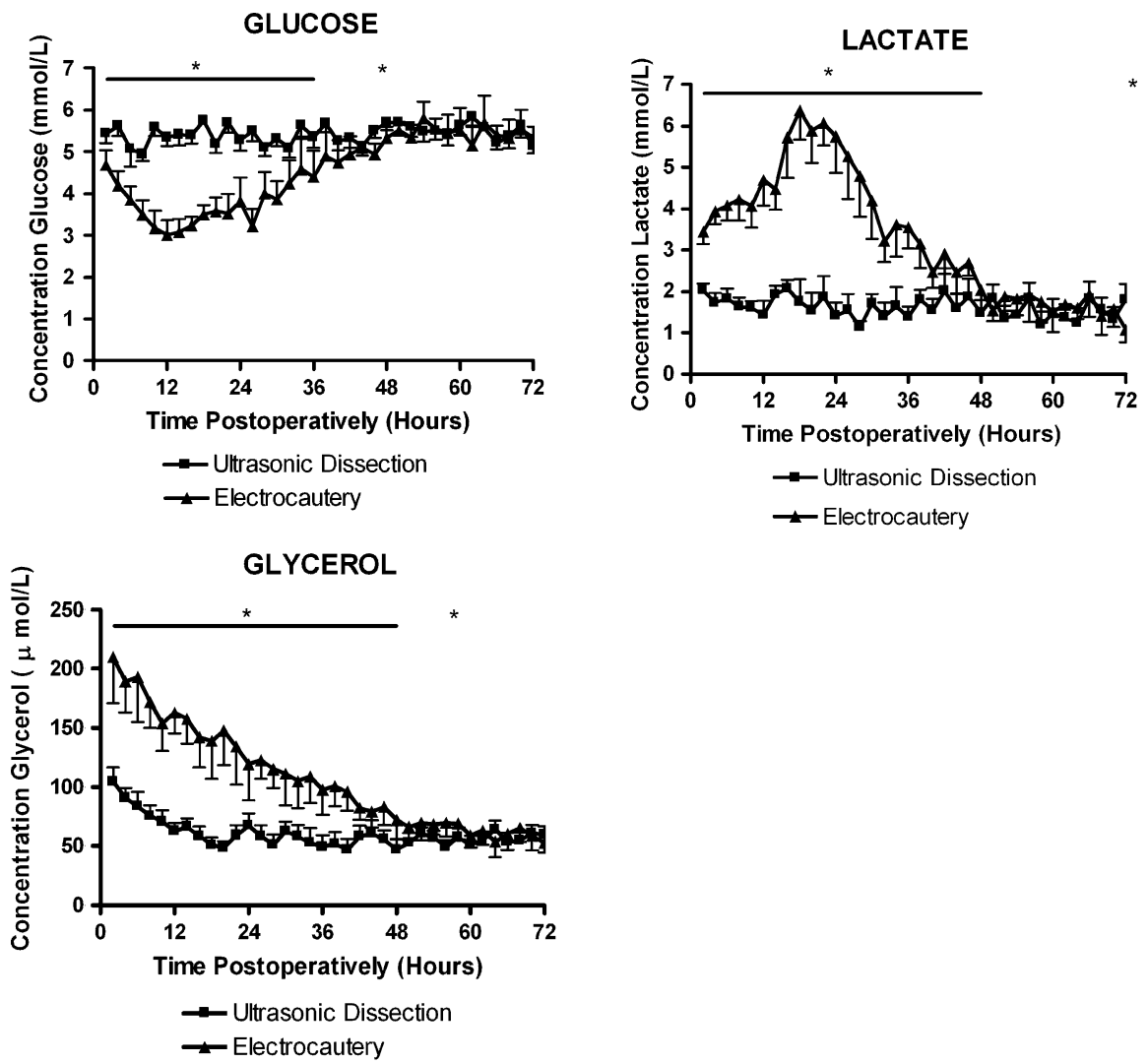

LACTATE/PYRUVATE RATIO

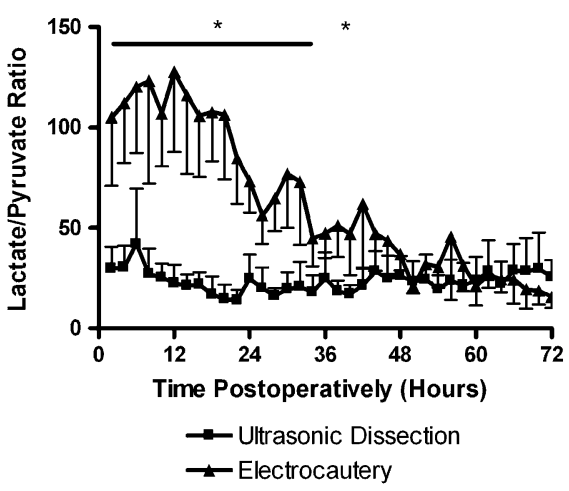

LACTATE/GLUCOSE RATIO

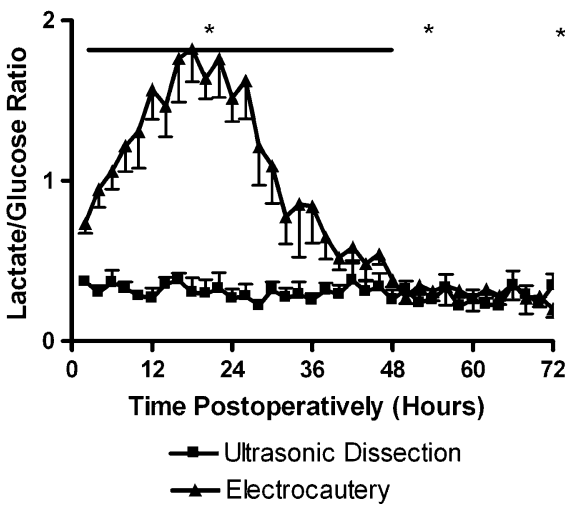

mean AUC of the lactate-glucose ratio was significantly higher in the EC group than in the UD group. (59 vs. 21; $P=0.008$; Table 1).

\section{Discussion}

The current study demonstrates that electrocautery causes more ischemic peritoneal tissue damage than ultrasonic dissection. Ultrasonic surgery had no effect or only a transient ischemic effect on peritoneal tissue and therefore fits well into the principia of "good surgical technique."

Microdialysis was proved useful in continuously measuring peritoneal extracellular chemistry. The inserted semipermeable membrane allowed a continuous diffusion of molecules out of the peritoneal interstitional space fluid into the perfusate medium for the whole study period without any failure.

Extracellular concentrations of glucose, pyruvate, lactate, and glycerol are broadly used as indicators of tissue hypoxia [5-14]. During ischemia, impaired blood flow decreases the delivery of glucose and oxygen to the tissue, forcing it to switch from aerobic to anaerobic metabolism $[15,16]$. The result is an increase in lactate, and if the glucose supply is inadequate, also a decrease in pyruvate level.

The rise in interstitional glycerol level is related to membrane phospholipid degradation, indicating tissue 
Table 1 Area under curve (AUC)

\begin{tabular}{llll}
\hline Dialysate & UD $(n=9)$ & EC $(n=9)$ & $P$ value \\
\hline Glucose $(\mathrm{mmol} / \mathrm{l}$ h) & & \\
Mean & 380.3 & 316.1 & 0.008 \\
Range & $357.1-395.6$ & $282.2-354.3$ & \\
SD & 11.57 & 22.43 & \\
Lactate $(\mathrm{mmol} / \mathrm{l}$ h) & & 0.008 \\
Mean & 112.3 & 232.7 & \\
Range & $96.5-155.0$ & $185.8-276.0$ & \\
SD & 22.2 & 36.9 & 0.008 \\
Glycerol $(\mu \mathrm{mol} / 1$ h) & & \\
Mean & 4169.4 & 7437.6 & \\
Range & $3162-4751$ & $4778-8872$ & \\
SD & 602.1 & 1210.1 & \\
Lactate-Pyruvate & ratio & & \\
Mean & 1639.2 & 4387.0 & \\
Range & $839.2-3307.0$ & $2563-6734$ & \\
SD & 768.9 & 1513.9 & \\
Lactate-glucose & ratio & & \\
Mean & 20.8 & 59.1 & \\
Range & $17.3-29.2$ & $44.1-70.5$ & \\
SD & 4.2 & 8 & \\
\hline
\end{tabular}

$P$ values are for the differences between UD and EC

$U D$ ultrasonic dissection, $E C$ electrocautery, $S D$ standard deviation

damage [7]. Although hyperlactatemia frequently is used as an indicator of anaerobic metabolism [6], its accumulation also can be caused by other conditions such as hypermetabolism, alkalosis, hepatic failure, toxins, and sepsis [6, 17, 18]. Therefore, the lactate-pyruvate ratio is a more reliable tissue-specific indicator of visceral ischemia $[6,8-11,14$, 18]. It correlates with the redox potential [6] and is less susceptible to artifacts caused by alterations in the dialysate recovery rate [8]. The immediate rise in the lactate-pyruvate ratio, reflecting sudden ischemia and inducing tissue necrosis, accords with the pathology of the coagulation injury.

The immediate rise in glycerol, another sensitive cell membrane marker for ischemia, further supports early cell damage. The lactate-glucose ratio provides an understanding of the qualitative relation between the ischemic glycolysis substrate and the end product and therefore is elevated in tissue ischemia [12]. This elevation starts later than that of the lactate-pyruvate ratio, reaching a peak after $24 \mathrm{~h}$, making the lactate-glucose ratio a less reliable parameter measuring early ischemia in this model. Within 48 to $72 \mathrm{~h}$ postoperatively, no difference was seen any longer between the two treatment groups, suggesting a rapidly developing but short-lasting ischemia and a rapid peritoneal healing response.

Ultrasonic dissection caused almost no tissue damage in the current study. In an animal study of peritonitis, control subjects undergoing a sham operation (laparotomy and peritoneal insertion of a microdialysis catheter) showed patterns of ischemic indices corresponding with those of the ultrasonic group [19]. Less injury by using ultrasonic dissection rather than electrocautery also was demonstrated in histologic biopsies of vascular endothelium, abdominal fascia, and bile duct $[3,20,21]$. This accords with various clinical studies showing fewer gallbladder perforations during laparoscopic cholecystectomy, fewer symptomatic lymphoceles after paraaortic lymphadenectomy, less necrosis after flap reconstruction, and less postoperative pain after gynecologic surgery and tonsillectomies, all explained by less tissue necrosis and inflammation [22-27].

Others have reported less favorable results with use of the ultrasonically activated scalpel related to high heat production, activation longer than $10 \mathrm{~s}$, and slow cooldown after the instrument is turned off $[4,28]$. The use of a scalpel versus a hook, the duration of instrument activation, the different tissues examined (well-vs. poor- vascularized tissue), and the tissue contact after application explain the differences in findings between studies. The short duration of peritoneal contact with a hook probably explains the more favorable outcome in our study than in the study of Kim et al [4]. Lateral thermal injury also was less in pig intestine and abdominal wall when energy was applied with pauses in contrast to the continuous activation of the Harmonic Scalpel [29].

Placement of the catheter itself did not seem to influence the current data, as deduced from the minimal changes in the UD group. Because of catheter placement, we did not control for peritoneal tissue responses through measurements, for example, in the subcutaneous tissue, as many studies do. A previous study demonstrated the same pattern recorded over time for catheters placed intraperitoneally and subcutaneously [17].

In daily practice, electrocautery is more frequently used than ultrasonic dissection despite multiple clinical studies indicating a superiority of the latter in causing less tissue damage, as evidenced by a decrease in gallbladder and intestine perforations during surgery and a reduction in complication rates for various abdominal, vascular, cardiac, and plastic surgeries [15, 22-25, 30-38]. The results of our study support a more frequent use of ultrasonic dissection in abdominal and pelvic surgery.

A favorable consequence of less tissue ischemia is the reduction in adhesion formation. Notably, the use of sutures was associated with a lower adhesion score compared with electrocautery in a small randomized controlled trial [39]. Adhesion formation was not a primary end point in the current study because 3 days of microdialysis was too short for accurate scoring of adhesions. A longer duration of microdialysis was deemed hazardous because of an increased risk of catheter blocking and foreign body reaction, which would introduce adhesions. 
It is concluded that the metabolic profiles in the current study resemble tissue ischemia with the use of ultrasonic surgery compared with electrocautery. In terms of optimal surgical technique, therefore, ultrasonic dissection is the preferred over electrocautery.

Acknowledgments The authors gratefully acknowledge the expert advice of Jan Hendriks from the department of Epidemiology and Biostatistics, University of Nijmegen, The Netherlands.

Disclosures Richard ten Broek, Joyce Wilbers, and Harry van Goor have no conflicts of interest or financial ties to disclose.

Open Access This article is distributed under the terms of the Creative Commons Attribution Noncommercial License which permits any noncommercial use, distribution, and reproduction in any medium, provided the original author(s) and source are credited.

\section{References}

1. van der Wal JB, Jeekel J (2007) Biology of the peritoneum in normal omeostasis and after surgical trauma. Colorectal Dis 9(Suppl 2):9-13

2. Brazio PS, Laird PC, Xu C, Gu J, Burris NS, Brown EN, Kon ZN, Poston RS (2008) Harmonic scalpel versus electrocautery for harvest of radial artery conduits: reduced risk of spasm and intimal injury on optical coherence tomography. J Thorac Cardiovasc Surg 136:1302-1308

3. Erkut B, Unlu Y, Karapolat S, Ugur KC, Ceviz M, Becit N, Kocak H (2008) Comparison of harmonic scalpel and high-frequency electrocautery in radial artery harvesting. J Cardiovasc Surg Torino 49:371-379

4. Kim FJ, Chammas MF Jr, Gewehr E, Morihisa M, Caldas F, Hayacibara E, Baptistussi M, Meyer F, Martins AC (2008) Temperature safety profile of laparoscopic devices: Harmonic ACE (ACE), Ligasure V (LV), and plasma trisector (PT). Surg Endosc 22:1464-1469

5. Muller M (2002) Science, medicine, and the future: Microdialysis. BMJ 324:588-591

6. Cabrera ME, Saidel GM, Kalhan SC (1999) A model analysis of lactate accumulation during muscle ischemia. J Crit Care 14:151-163

7. Hillered L, Valtysson J, Enblad P, Persson L (1998) Interstitial glycerol as a marker for membrane phospholipid degradation in the acutely injured human brain. J Neurol Neurosurg Psychiatry 64:486-491

8. Hlatky R, Valadka AB, Goodman JC, Contant CF, Robertson CS (2004) Patterns of energy substrates during ischemia measured in the brain by microdialysis. J Neurotrauma 21:894-906

9. Jansson K, Jansson M, Andersson M, Magnuson A, Ungerstedt U, Norgren L (2005) Normal values and differences between intraperitoneal and subcutaneous microdialysis in patients after noncomplicated gastrointestinal surgery. Scand J Clin Lab Invest 65:273-281

10. Jansson K, Ungerstedt J, Jonsson T, Redler B, Andersson M, Ungerstedt U, Norgren L (2003) Human intraperitoneal microdialysis: increased lactate/pyruvate ratio suggests early visceral ischaemia: a pilot study. Scand J Gastroenterol 38:1007-1011

11. Nilsson OG, Brandt L, Ungerstedt U, Saveland H (1999) Bedside detection of brain ischemia using intracerebral microdialysis: subarachnoid hemorrhage and delayed ischemic deterioration. Neurosurgery 45:1176-1184
12. Pokela M, Biancari F, Rimpilainen J, Romsi P, Hirvonen J, Vainionpaa V, Kiviluoma K, Anttila V, Juvonen T (2001) The role of cerebral microdialysis in predicting the outcome after experimental hypothermic circulatory arrest. Scand Cardiovasc J 35:395-402

13. Sarrafzadeh AS, Sakowitz OW, Kiening KL, Benndorf G, Lanksch WR, Unterberg AW (2002) Bedside microdialysis: a tool to monitor cerebral metabolism in subarachnoid hemorrhage patients? Crit Care Med 30:1062-1070

14. Zoremba N, Homola A, Rossaint R, Sykova E (2007) Brain metabolism and extracellular space diffusion parameters during and after transient global hypoxia in the rat cortex. Exp Neurol 203:34-41

15. Diamantis T, Kontos M, Arvelakis A, Syroukis S, Koronarchis D, Papalois A, Agapitos E, Bastounis E, Lazaris AC (2006) Comparison of monopolar electrocoagulation, bipolar electrocoagulation, Ultracision, and Ligasure. Surg Today 36:908-913

16. Holmdahl L, Eriksson E, Eriksson BI, Risberg B (1998) Depression of peritoneal fibrinolysis during operation is a local response to trauma. Surgery 123:539-544

17. Jansson K, Strand I, Redler B, Magnuson A, Ungerstedt U, Norgren L (2004) Results of intraperitoneal microdialysis depend on the location of the catheter. Scand J Clin Lab Invest 64:63-70

18. Nowak G, Ungerstedt J, Wernerman J, Ungerstedt U, Ericzon BG (2002) Clinical experience in continuous graft monitoring with microdialysis early after liver transplantation. Br J Surg 89: $1169-1175$

19. Pierie ME, van Goor H (2005) Peritonitis causes ischemia of the peritoneum: a novel approach to continuously monitor intraabdominal sepsis [Abstract]. In: 25th Annual Meeting of the Surgical Infection Society - North America, 5-7 May 2005, Miami, FL, SIS-NA, p 24, Abstract nr 125

20. Wetter LA, Payne JH, Kirshenbaum G, Podoll EF, Bachinsky T, Way LW (1992) The ultrasonic dissector facilitates laparoscopic cholecystectomy. Arch Surg 127:1195-1198

21. Ozgun H, Tuncyurek P, Boylu S, Erpek H, Yenisey C, Kose H, Culhaci N (2007) The right method for midline laparotomy: what is the best choice for wound healing? Acta Chir Belg 107:682686

22. Cengiz Y, Janes A, Grehn A, Israelsson LA (2005) Randomized trial of traditional dissection with electrocautery versus ultrasonic fundus-first dissection in patients undergoing laparoscopic cholecystectomy. Br J Surg 92:810-813

23. Janssen IM, Swank DJ, Boonstra O, Knipscheer BC, Klinkenbijl $\mathrm{JH}$, van Goor H (2003) Randomized clinical trial of ultrasonic versus electrocautery dissection of the gallbladder in laparoscopic cholecystectomy. Br J Surg 90:799-803

24. Inaba H, Kaneko Y, Ohtsuka T, Ezure M, Tanaka K, Ueno K, Takamoto S (2000) Minimal damage during endoscopic latissimus dorsi muscle mobilization with the harmonic scalpel. Ann Thorac Surg 69:1399-1401

25. Deo S, Hazarika S, Shukla NK, Kar M, Samaiya A (2005) A prospective randomized trial comparing harmonic scalpel versus electrocautery for pectoralis major myocutaneous flap dissection. Plast Reconstr Surg 115:1006-1009

26. Potts KL, Augenstein A, Goldman JL (2005) A parallel group analysis of tonsillectomy using the harmonic scalpel vs. electrocautery. Arch Otolaryngol Head Neck Surg 131:49-51

27. Litta P, Fantinato S, Calonaci F, Cosmi E, Filippeschi M, Zerbetto I, Petraglia F, Florio P (2009) A randomized controlled study comparing harmonic versus electrosurgery in laparoscopic myomectomy. Fertil Steril 94:1882-1886

28. Emam TA, Cuschieri A (2003) How safe is high-power ultrasonic dissection? Ann Surg 237:186-191

29. Pogorelic Z, Perko Z, Druzijanic N, Tomic S, Mrklic I (2009) How to prevent lateral thermal damage to tissue using the 
harmonic scalpel: experimental study on pig small intestine and abdominal wall. Eur Surg Res 43:235-240

30. Davidoff AM, Pappas TN, Murray EA, Hilleren DJ, Johnson RD, Baker ME, Newman GE, Cotton PB, Meyers WC (1992) Mechanisms of major biliary injury during laparoscopic cholecystectomy. Ann Surg 215:196-202

31. Deziel DJ, Millikan KW, Economou SG, Doolas A, Ko ST, Airan MC (1993) Complications of laparoscopic cholecystectomy: a national survey of 4, 292 hospitals and an analysis of 77, 604 cases. Am J Surg 165:9-14

32. Kubo G, Sahm M (2003) The role of the ultracision technique in visceral surgery: ligature-free operation: an illusion? Zentralbl Chir 128:1062-1065

33. Luciani N, Anselmi A, Gaudino M, Nasso G, Glieca F, Martinelli L, Santarelli F, Perisano M, Possati G (2005) Harmonic scalpel reduces bleeding and postoperative complications in redo cardiac surgery. Ann Thorac Surg 80:934-938

34. Martin RF, Rossi RL (1994) Bile duct injuries: spectrum, mechanisms of injury, and their prevention. Surg Clin North Am $74: 781-803$
35. Orejola WC, Villacin AB, Defilippi VJ, Mekhjian HA (2000) Internal mammary artery harvesting using the harmonic scalpel. ASAIO J 46:99-102

36. Oz BS, Mataraci I, Iyem H, Kuralay E, Doganci S, Demirkilic U, Yokusoglu M, Tatar H (2007) Comparison of ultrasonically activated scalpel and traditional technique in radial artery harvesting: clinical research. Thorac Cardiovasc Surg 55:104107

37. Swank DJ, Van Erp WF, Repelaer Van Driel OJ, Hop WC, Bonjer HJ, Jeekel H (2003) A prospective analysis of predictive factors on the results of laparoscopic adhesiolysis in patients with chronic abdominal pain. Surg Laparosc Endosc Percutan Tech 13:88-94

38. Swank DJ, Bonjer HJ, Jeekel J (2002) Safe laparoscopic adhesiolysis with optical access trocar and ultrasonic dissection: a prospective study. Surg Endosc 16:1796-1801

39. Pellicano M, Bramante S, Guida M, Bifulco G, Di Spiezio SA, Cirillo D, Nappi C (2008) Ovarian endometrioma: postoperative adhesions following bipolar coagulation and suture. Fertil Steril 89:796-799 